\title{
Pengujian Theory Of Planned Behavior Dalam Memprediksi Niat Polisi Menggunakan Sistem Penilaian Kinerja Online Pada Polsek Seririt Kabupaten Buleleng
}

\author{
K.G.D Cantika ${ }^{1}$, N.M Suci ${ }^{2}$ \\ 1,2 Jurusan Manajemen, Universitas Pendidikan Ganesha, Singaraja \\ e-mail: gayatricantika16@gmail.com, madesuci_bali@yahoo.com
}

\begin{abstract}
Abstrak
Penelitian ini bertujuan untuk menguji pengaruh Theory of Planned Behavior terhadap niat menggunakan sistem penilaian kinerja (SPK) online. Desain penelitian ini menggunakan kuantitatif kausal. Penelitian ini dilakukan terhadap 40 orang polisi yang berusia 30 tahun dan masa kerja minimal 10 tahun. Data dikumpulkan dengan metode kuesioner dan dianalisis dengan menggunakan analisis regresi linier berganda. Hasil penelitian menunjukkan bahwa ada pengaruh positif dan signifikan dari (1) sikap terhadap niat menggunakan SPK online, (2) norma subjektif terhadap niat menggunakan SPK online, (3) perceived behavior control terhadap niat menggunakan SPK dan (4) sikap, norma subjektif dan perceived behavior control terhadap niat menggunakan SPK online. Hal ini berarti jika ingin meningkatkan niat menggunakan SPK online, maka pihak setaraf pimpinan atau kepala unit pada Polsek Seririt harus memastikan anggotanya memiliki sikap positif, dukungan masing-masing anggota untuk saling memahami dan mengajarkan serta kontrol diri dalam menggunakan SPK online.
\end{abstract}

Kata kunci: niat, sistem penilaian kinerja online dan Theory of Planned Behavior

\section{Abstract}

This study aimed to clarify the effect of Theory of Planned Behavior on the intentions use an online performance evaluation system (SPK). This research used a causal quantitative design. 40 police officers aged 30 years and a minimum working period of 10 years were involved in this research. Data were collected used questionnaire method and analyzed using multiple linear regression analysis. The results showed that there were positive and significant influences from (1) attitudes toward intentions using online SPK, (2) subjective norms on intentions using online SPK, (3) perceived behavior control on intentions using SPK and (4) attitudes, subjective norms and perceived behavior control of intentions using online SPK. This means that if want to increase intention to use SPK online, then the commander must ensure that members have a positive attitude, support each member to understand each other and teach and control themselves in using the SPK online.

Keyword: intention, online performance appraisal system, Theory of Planned Behavior

\section{Pendahuluan}

Kunci dari keberlangsungan suatu organisasi di era globalisasi saat ini adalah sumber daya manusia. Sumber daya manusia termasuk ke dalam aset suatu organisasi yang relative sulit untuk ditiru oleh organisasi lain. Bagi instansi pemerintah tersedianya sumber daya manusia yang berkualitas, memiliki keterampilan tinggi serta professional dalam sektor jasa pelayanan menjadi salah satu syarat untuk meningkatkan kualitas penyelenggaraan negara serta memberikan kepuasan terhadap kualitas jasa pelayanan dari pemerintah terhadap masyarakat.

Neely et al (1995) menyatakan bahwa Sistem Penilaian Kinerja adalah suatu sistem yang mengukur tindakan yang dilakukan dan secara spesifik sistem penilaian kerja dapat diartikan sebagai tolak ukur yang digunakan untuk mengukur efektivitas serta efesiensi suatu tindakan. Sistem penilaian kinerja mempunyai manfaat yang sangat penting bagi suatu organisasi karena bisa memberikan suatu informasi yang sangat relevan terhadap pekerjaan serta memotivasi pekerja untuk meningkatkan kinerjanya. Sistem penilaian kinerja yang digunakan Kepolisian di Polsek Seririt yakni adalah menggunakan sistem penilaian kinerja online. 
Sistem penilain kerja online merupakan suatu sistem informasi yang memberikan laporan mengenai kinerja anggota Polri yang mendukung manajemen kerja secara keseluruhan. Penilaian yang berdasarkan standar kinerja secara transparan, objektif serta akuntabel yang bertujuan untuk mendorong produktivitas, dedikasi, prestasi serta loyalitas dalam bekerja sangat diperlukan guna meningkatkan dan mengembangkan kinerja pegawai negeri dan polri. Sebelum diterapkannya SPK online, SPK yang digunakan masih manual dimana setiap anggota masih mengisi selembaran. Dengan diterapkannya SPK online informasi akan cepat dikirimkan kepada pengolah data melalui internet, sehingga informasinya akan teratur, cepat, jelas dan tepat.

Dengan adanya SPK online akan memudahkan dalam pengolahan data evaluasi anggota polisi. Sehingga dengan adanya SPK yang berbasis online memudahkan anggota dalam melakukan proses pengolahan data dengan harapan bisa memberikan sebuah informasi yang lebih jelas dan akurat. Berdasarkan wawancara awal, disisi lain dengan adanya SPK online yang diterapkan saat ini anggota memiliki kecenderungan untuk enggan belajar menggunakan SPK online tersebut. Padahal sudah diberikan pelatihan tentang cara menggunakan SPK online. Peneliti merasa bahwa ada beberapa faktor yang membuat anggota polisi enggan menggunakannya dan lebih mengandalkan rekan kerjanya.

Salah satu teori yang sering digunakan dalam penelitian prilaku adalah Theory of Planned Behavior (TPB). Dalam teori ini memadukan antara sikap terhadap perilaku, norma subjektif serta perceived behavior control yang membentuk niat perilaku yang kemudian membentuk suatu perilaku (Jogiyanto, 2008). Terdapat tiga macam pertimbangan yang mendasari perilaku manusia berdasarkan TPB yakni keyakinan terhadap kecenderungan hasil positif atau negatif suatu perilaku (behavior belief), keyakinan akan harapan seseorang yang sifatnya normative (normative belief) serta keyakinan terhadap munculnya beberapa faktor yang menimbulkan perilaku (control belief) (Jogiyanto, 2007). Keyakinan terhadap suatu objek merupakan salah satu faktor personal yang memberikan pengaruh terhadap sikap seseorang.

Pembentukan sikap beberapa orang dipengaruhi oleh keyakinan yang berasal dari pengalaman pribadi orang tersebut. Hal ini menandakan bahwa pandangan subjektif serta objektif masih mempengaruhi perilaku seseorang. Dalam pembentukan sikap, sangat bergantung pada niat serta kecenderungan yang kuat dari seseorang dan mengakibatkan suatu perilaku. Niat akan menghubungkan sikap dengan perilaku yang akan diperlihatkan oleh seseorang. Demikian halnya saat individu memutuskan untuk memperlihatkan perilaku menggunakan SPK online. Berdasarkan penelitian yang dilakukan oleh Taylor dan Todd (1995) menyatakan apabila TPB dapat memberikan pemahaman yang lebih lengkap dalam menjelaskan mengenai niat perilaku serta penggunaan.

Sikap terhadap SPK online akan mempengaruhi niat seseorang untuk menggunakan SPK online. Niat untuk menggunakan SPK online semakin meningkat apabila sikapnya positif. Sedangkan jika sikapnya negatif, maka akan menurunkan niatnya untuk menggunakan SPK online. Hasil Penelitian yang dilakukan oleh Wikamorys dan Rochmach (2017) menemukan bahwa sikap berpengaruh positif terhadap niat. Hal ini sejalan dengan hasil penelitian oleh Mirawati, dkk (2016) menemukan bahwa sikap berpengaruh positif dan signifikan terhadap niat. Semakin positif sikap menggunakan SPK online maka niat untuk menggunakan SPK online akan semakin besar.

Norma subjektif terhadap niat akan mempengaruhi niat seseorang untuk menggunakan SPK online. Norma subjektif dapat diartikan sebagai pengaruh dari pihak luar terhadap individu. Apabila pihak luar seperti keluarga, rekan kerja serta pimpinan memberikan dukungan kepada anggota polisi untuk menggunakan SPK online, maka niat dari polisi tersebut akan meningkat untuk menggunakannya. Begitu sebaliknya, niatnya akan menurun apabila mendapat tentangan dari pihak luar. Dalam penelitian terdahulu yang dilakukan oleh Wikarmorys dan Rochmach (2017) menjelaskan bahwa norma subjektif memberikan pengaruh yang positif terhadap niat. Hasil penelitian ini sejalan dengan penelitian yang dilakukan oleh Ruslim, dkk yang menemukan hal yang sama yaitu norma subjektif memberikan pengaruh positif terhadap niat. 
Perceived Behavior Control (PBC) terhadap niat akan mempengaruhi niat seseorang untuk menggunakan SPK online. TBC dapat diartikan sebagai penilaian seseorang terhadap kesulitan atau kemudahan ketika melakukan sesuatu. Niat polisi akan meningkat dalam menggunakan SPK online ketia ia merasa kesulitan yang dia alami Ketika menggunakannya dapat diatasi dengan mudah. Sedangkan jika bagi mereka kesulitan yang dialami tidak dapat ditangani, maka niat mereka menggunakan SPK online pun menurun. Penelitian yang telah dilakukan oleh Ruslim, dkk (2017) membuktikan bahwa PBC memberikan pengaruh yang signifikan terhadap niat. Hal ini sesuai dengan penelitian yang telah dilakukan oleh Wikamorys dan Rochman (2017) yang menujukkan bahwa PBC memberikan pengaruh yang positif terhadap niat. Berbeda dengan penelitian yang dilakukan oleh Yudhi, dkk (2005) yang mengatakan bahwa PBC memberikan pengaruh yang negatif terhadap niat.

Kajian pustaka dalam penelitian yang dilakukan yaitu adanya hubungan theory of planned behavior dalam memprediksi niat menggunakan sistem penilaian kinerja online. Sikap terhadap perilaku individual menjadi penentu niat yang memiliki hubungan dengan faktor pribadi (Jogianto 2008). Yang mendasari sikap seseorang terhadap perilaku adalah belief seseorang terhadap konsekuensi (outcome) yang ditimbulkan. Sikap terhadap perilaku dapat diartikan sebagai sejauh mana kinerja dari perilaku mendapat penghargaan. Sikap (attitude) merupakan penilaian dari kepercayaan (belief) atau perasaan positif maupun negative yang dimiliki seseorang apabila melakukan perilaku yang akan ditentukan (Jogiyanto, 2008).

Sikap diartikan sebagai keyakinan atau tanggapan seseorang mengenai suatu hal yang menguntungkan atau merugikan untuk melakukan prilaku yang akan ditentukan. Sikap positif dari olisi akan terbentuk apabila SPK online memberikan manfaat baginya yang mengakibatkan niatnya meningkat menggunakan SPK online. Namun, apabila SPK online dirasa kurang menguntungkan baginya, maka akan terbentuk sikap negatif dari polisi tersebut sehingga niatnya untuk menggunakan SPK online menurun. Hal ini sejalan dengan penelitian terdahulu yang dilakukan oleh Wikamorys dan Rochmach (2017) yang menjelaskan adanya pengaruh positif dari sikap terhadap niat. H1: Ada pengaruh sikap terhadap niat menggunakan sistem penilaian kerja online.

Selain sikap, pengaruh social seperti norma subjektif juga dapat mempengaruhi niat (Jogiyanto, 2008). Norma subjektif merupakan suatu pandangan individu kepada individu lain atau kelompok tertentu yang setuju ataupun tidak terhadap prilakunya serta dorongan dan motivasi yang diberikan oleh mereka agar seseorang berperilaku tertentu. Orang sekitar yang berpotensi memberikan pengaruh antara lain keluarga, teman, ataupun pimpinan. Berdasarkan hasil penelitian yang dilakukan oleh Ruslim, dkk (2017) membuktikan bahwa norma subjektif memberikan pengaruh yang positif terhadap niat. Diyakini bahwa apabila seseorang mendapat refrensi dalam perilaku yang harus dilakukannya, maka niatnya (intentions) akan dipengaruhi oleh norma subjektif agar melakukan perilaku tertentu. hal ini juga didukung oleh penelitian Wikamorys dan Rochmach (2017) membuktikan adanya pengaruh positif dari norma subjektif terhadap niat. H2: Ada pengaruh norma subjektif terhadap niat menggunakan sistem penilaian kerja online.

Kontrol prilaku yang telah dipersiapkan dapat memberikan pengaruh terhadap niat yang didasari oleh asumsi bahwa kontrol perilaku yang telah dipersiapkan dapat memberikan implikasi motivasi untuk orang yang telah mempersiapkannya, hal ini dikemukakan oleh Ajzen (1991). Menurut Jogiyanto (2008) menyebutkan bahwa PBC diakibatkan oleh adaya control beliefs yaitu kepercayaan terhadap adanya beberapa faktor yang mempengaruhi perilaku. Jika seseorang memiliki kepercayaan terhadap kemampuan yang diperlukan dalam menggunakan SPK online secara penuh serta sesuai prosedur, maka kemungkinan niatnya untuk menggunakan SPK online semakin meningkat kemudian pada akhirnya akan menggunakannya secara maksimal untuk menghasilkan kinerja terbaik.

Sesuai dengan theory of planned behavior oleh Ajzen \& Fishben (1970), terdapat faktor yang mempunyai karakteristik memperkuat dan memperlemah niat yaitu faktor pengendalian prilaku. Niat akan melemah apabila prilaku sulit dikendalikan atau tidak mungkin dilakukan. Hal ini sesuai dengan penelitian terdahulu yang dilakukan oleh Ruslim, dkk (2017) menentukan PBC berpengaruh signifikan terhadap niat. Hasil tersebut berbeda 
dengan hasil penelitian yang dilakukan oleh Yudhi, dkk (2015) yang membuktikan bahwa PBC memberikan pengaruh negatif terhadap niat. H3: Ada pengaruh perceived behavior control terhadap niat menggunakan sistem penilaian kerja online.

Sikap terhadap SPK online memberikan pengaruh terhadap niat seseorang dalam menggunakan SPK online. Jika sikap yang ditunjukkan positif, maka niat untuk menggunakan SPK online akan meningkat. Sedangkan niat akan menurun apabila sikap yang ditunjukkan terhadap SPK online negatif. Pengaruh dari pihak luar atau yang disebut norma subjektif juga dapat mempengaruhi niat seseorang. Jika orang lain memberikan dukungan, maka niat polisi dalam menggunakan SPK online akan meningkat. Sebaliknya apabila polisi tidak mendapat dukungan dari pihak luar maka niatnya dalam menggunakan SPK online akan menurun. Sehingga berdasarkan Theory of Planned Behavior, terdapat tiga hal yang mempengaruhi niat yakni sikap terhadap perilaku, norma subjektif, serta kontrol perilaku persiapan.

Dharmmesta (1998) dalam bukunya menyatakan bahwa niat dapat menggambarkan usaha yang telah dilakukan seseorang dalam mencoba sesuatu. Niat dapat diartikan sebagai suatu usaha yang dilakukan secara sadar dalam mencapai suatu tujuan ataupun sasaran yang sudah didefinisikan dengan jelas (Fishbein, 2007). Dalam Theory of Planned Behavior menerangkan bahwa suatu prilaku akan timbul apabila seseorang mempunyai keinginan ataupun suatu rencana dalam melakukannya. Semakin kuat kinginan yang dimiliki akan mengakibatkan semakin kuat niat dalam menampilkan suatu perilaku (Jogiyanto, 2007). Kemudahan atau kesulitan seseorang dalam melakukan sesuatu dinilai dengan PBC (perceived behavior control). Niat polisi dalam menggunakan SPK online akan meningkat apabila kesulitan dalam menggunakan SPK online dapat diatasi. Sedangkan niatnya akan menurun dalam menggunakan SPK online apabila ia menganggap dirinya kurang mampu mengatasi kesulitan dalam menggunakannya.

Berdasarkan uraian diatas, Sikap, Norma Subjektif serta PBC secara bersamaan akan berpengaruh positif terhadap Niat Polisi untuk menggunakan SPK online. Pernyataan ini sejalan dengan penelitian terdahulu yang dilakukan oleh Wikamorys dan Rochmach (2017) dan Mirawati, dkk (2016) yang menyatakan bahwa pengaruh yang signifikan diberikan oleh sikap, norma subjektif serta PBC terhadap niat. H4: Ada pengaruh sikap, norma subjektif, dan PBC terhadap niat menggunakan sistem penilaian kerja online.

\section{Metode}

Rancangan dalam penelitian ini menggunakan kuantitatif kausal yang digunakan untuk mendapatkan eksplansi yang teruji mengenai pengaruh sikap $\left(X_{1}\right)$, norma subjektif $\left(\mathrm{X}_{2}\right)$, PBC $\left(\mathrm{X}_{3}\right)$ terhadap niat $(\mathrm{Y})$. dalam penelitian ini, variabel bebas yang diambil ada tiga yaitu sikap, norma subjektif dan PBC, kemudian variabel terikat yang diambil adalah niat polisi dalam menggunakan SPK online.

Subjek dalam penelitian ini adalah Polsek Seririrt Kabupaten Buleleng dan objek dalam penelitian ini adalah sikap, norma subjektif, PBC dan niat menggunakan SPK online. Populasi yang diambil adalah 40 orang polisi dengan umur minimal 30 tahun dan masa kerja minimal 10 tahun.

Dalam penelitian ini menggunakan kuesioner sebagai teknik mengumpulkan data. Kuesioner merupakan sekumpulan pertanyaan atau pernyataan tertulis yang harus dijawab oleh responden (Arikunto, 2013). Kuesioner yang digunakan dalam penelitian ini menggunakan skala Likert dengan skor 1-5. Skala Likert dapat digunakan dalam mengukur sikap ataupun pendpat seseorang mengenai suatu fenomena sosial.

Teknik analisis data yang diterapkan dalam penelitian ini adalah analisis linear berganda dengan bantuan program Statistic Package for Social Science (SPSS) 25.0 for windows untuk menguji hipotesis. Sebelum data diolah dengan analisis regresi berganda, terlebih dahlu dilakukan uji asumsi klasik yang terdiri dari uji normalitas, uji multikolinearitas dan uji heteroskedastisitas. 


\section{Hasil dan Pembahasan}

Hasil Uji Analisis Regresi Linear Berganda sikap, norma subjektif serta PBC terhadap niat menggunakan SPK online dapat dilihat dalam Tabel 1.

\begin{tabular}{llllll}
\hline Model & \multicolumn{2}{c}{$\begin{array}{c}\text { Unstandarized of } \\
\text { Coefficients }\end{array}$} & $\begin{array}{c}\text { Standarized } \\
\text { Coefficiens }\end{array}$ & T & Sig \\
\cline { 2 - 4 } & $\mathrm{B}$ & S.E & Beta & & \\
\hline Constant & 2.369 & 0.860 & & 2.753 & 0.009 \\
Sikap & 0.201 & 0.083 & 0.379 & 2.420 & 0.021 \\
Norma & 0.304 & 0.149 & 0.238 & 2.047 & 0.048 \\
Subjektf & & & & & \\
PBC & 0.453 & 0.199 & 0.361 & 2.269 & 0.029 \\
\hline
\end{tabular}

Sumber: Lampiran 11 Hasil Output SPSS 25.0 for Windows

Dari table 1 dapat dilihat bahwa nilai konstanta $(\alpha)$ sebesar 2.369, nilai koefisien regresi sikap ( $\beta 1$ ) sebesar 0,201 , nilai koefisien regresi norma subjektif ( $\beta 2$ ) sebesar 0,304 , koefisien regresi PBC $(\beta 3)$ sebesar 0,453 . Sehingga persamaan regresi diformulasikan sebagai berikut:

$$
\begin{aligned}
& Y=\alpha+\beta 1 X 1+\beta 2 X 2+\beta 3 X 3+\varepsilon \\
& Y=2,369+0,201 X 1+0,304 X 2+0,453 X 3+\varepsilon
\end{aligned}
$$

Berdasarkan hasil uji regresi linier berganda pada tabel 1, maka diperoleh pengaruh masingmasing variabel terhadap niat menggunakan SPK online pada Polsek Seririt Kabupaten Buleleng dapat dilihat pada Gambar 1.

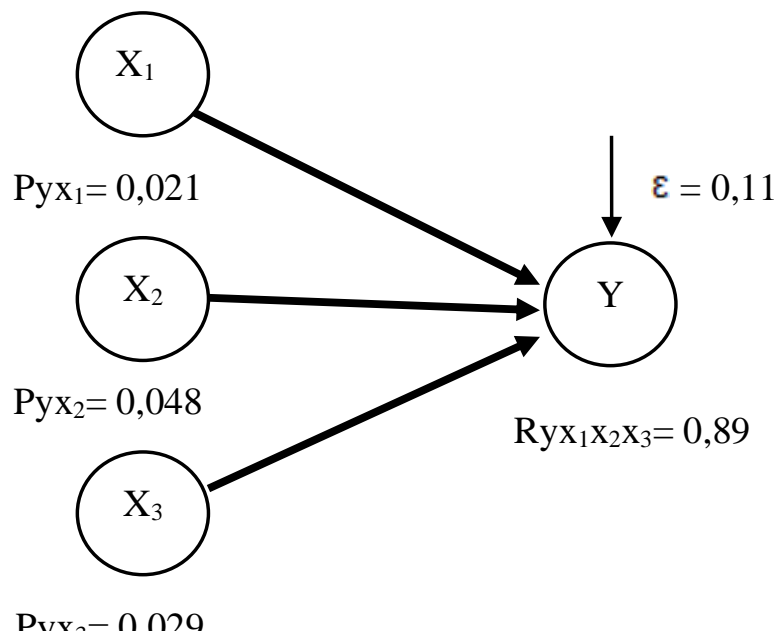

Gambar 1. Struktur Pengaruh Variabel Sikap, Norma Subjektif, PBC dan Niat Menggunakan SPK Online.

Berdasarkan persamaan regresi yang diperoleh maka interpretasi dari persamaan regresi tersebut dapat dijelaskan sebagai berikut.

Koefisien regresi variabel $\mathrm{X} 1$ atau sikap sebesar 0,201 maka dapat disimpulkan jika ada peningkatan setiap 1 satuan dari variabel sikap maka variabel dependent akan meningkat 0,201 ini berarti apabila sikap tinggi maka akan meningkatkan niat menggunakan SPK online. Nilai $p$-value $0,021<$ alpha 0,05 , sehingga $H_{1}$ diterima yang berarti ada pengaruh signifikan sikap terhadap niat menggunakan SPK online. 
Koefisien regresi variabel X2 atau norma subjektif sebesar 0,304 maka dapat disimpulkan jika ada peningkatan setiap 1 satuan dari variabel norma subjektif maka variabel dependent akan meningkat 0,304 ini berarti apabila norma subjektif tinggi maka akan meningkatkan niat menggunakan SPK online. Nilai $p$-value 0,048 < alpha 0,05, sehingga $\mathrm{H}_{2}$ diterima yang berarti ada pengaruh signifikan dari norma subjektif terhadap niat menggunakan SPK online.

Koefisien regresi variabel X3 atau PBC sebesar 0,453 maka dapat disimpulkan jika ada peningkatan setiap 1 satuan dari variabel PBC maka variabel dependent akan meningkat 0,453 ini berarti apabila PBC tinggi maka secara langsung niat menggunakan SPK online akan tinggi. Nilai $p$-value $0,029<$ alpha 0,05 , sehingga $\mathrm{H}_{3}$ diterima yang berarti ada pengaruh signifikan dari PBC terhadap niat menggunakan SPK online.

Konstanta senilai 2,369. Konstanta akan bernilai 2,369 jika variabel independent yaitu sikap, norma subjektif dan PBC bernilai nol (0) dan variabel dependent akan memiliki nilai yang sama dengan konstanta. Nilai $p$-value $0,009<$ alpha 0,05 , sehingga $\mathrm{H}_{4}$ diterima yang berarti ada pengaruh signifikan dari sikap, norma subjektif, dan PBC terhadap niat menggunkan SPK online.

Sikap memberikan pengaruh yang positif dan signifikan terhadap niat polisi dalam penggunaan SPK online. Hal ini menunjukkan semakin positif sikap polisi terhadap penggunaan SPK online maka semakin tinggi niat untuk menggunakannya. Penggunaan SPK online akan memudahkan anggota untuk melakukan penilaian kinerja dan menjaga agar data kinerja terarsipkan dengan baik dan sistematis. Hasil penelitian ini mendukung tepri TPB bahwa sikap terhadap perilaku individual dapat menentukan niat yang berhubungan dengan faktor pribadi. Sikap diartikan sebagai perasaan seseorang Ketika harus melakukan prilaku yang sudah ditentukan (Jogiyanto, 2008). Apabila sikap yang ditunjukkan polisi positif maka akan meningkatkan niatnya untuk menggunakan SPK online. Sebaliknya, niatnya akan menurun apabila sikapnya negative terhadap penerapan SPK online. Hal yang serupa juga dikemukakan dalam penelitian yang dilakukan oleh Mirawati, dkk (2016), Wikamorys \& Rochmach (2017) yang menemukan pengaruh positif serta signifikan dari sikap terhadap niat.

Sikap polisi terhadap penggunaan SPK online sudah tinggi dilihat dari tanggapannya terhadap variabel item kuesioner yakni sikap terhadap penggunaan SPK online memberikan pengaruh yang lebih besar daripada variabel lain yang diteliti, sehingga disimpulkan bahwa sikap memiliki kontribusi yang paling besar dalam penggunaan SPK online. Sikap menjadi variabel yang dominan dalam penggunaan SPK online karena sikap berasal adri keyakinan seseorang mengenai sikap yang akan dilakukan.

Selain sikap, norma subjektif juga memberikan pengaruh yang positif dan signifikan terhadap penggunaan SPK online, yang artinya norma subjektif telah berperan secara aktif dalam penggunaan SPK online. Sehingga anggota satu sama lain saling memotivasi dan membantu dalam penggunaan SPK online. Hasil dari penelitian ini dapat mendukung teori TPB yang mengatakan bahwa norma subjektif diartikan sebagai pengaruh yang diberikan oleh orang luar kepada seseorang. Jogiyanto (2007:42) menyatakan bahwa norma subjektif merupakan pandangan seseorang terhadap kepercayaan orang lain yang dapat memberikan pengaruh kepada orang tersebut untuk menentukan perilaku yang sedang menjadi pertimbangan. Jika polisi mendapatkan dukungan dari orang lain seperti keluarga, rekan kerja atau pimpinan, maka niatnya dalam menggunakan SPK online akan meningkat. Niatnya akan menurun apabila polisi tersebut tidak mendapatkan dukungan atau bertentangan dengan orang lain. Hasil penelitian ini sejalan dengan penelitian yang dilakukan oleh Ruslim, dkk (2017), Wikamorys dan Rochmach (2017) yang menemukan pengaruh positif dari norma subjektif terhadap niat.

Berdasarkan variabel item kuesioner, norma subjektif memiliki pengaruh yang signifikan terhadap niat penggunaan SPK online, dengan kata lain, jika motivasi polisi semakin besar dalam mengikuti saran daro orang yang penting, maka semakin besar pula niatnya untuk menggunakan SPK online. Dari Ketika variabel yang mempengaruhi niat penggunaan SPK online, norma subjektif memiliki pengaruh yang lebih kecil dibandingkan yang lainnya, hal ini mungkin disebabkan oleh lemahnya keyakinan individu terhadap saran 
dari orang lain serta motivasi yang didak terlalu besar dalam mematuhi sehingga tidak terlalu memberikan pengaruh yang besar dalam memunculkan niat.

PBC berpengaruh positif dan signifikan terhadap niat menggunakan SPK online pada Polsek Seririt Kabupaten Buleleng. jika PBC semakin tinggi, maka niat polisi menggunakan SPK online juga semakin tinggi. Polisi Polsek Seririt Kabupaten Buleleng sudah memiliki kontrol perilaku dan mampu mengimplikasikan motivasi pada diri sendiri. Polisi Polsek Seririt Kabupaten Buleleng yang menjadi responden memilikimempunyai kualifikasi dan kemampuan yang diperlukan ketika menggunakan SPK online secara penuh dan sesuai dengan prosedur, sehingga niatnya untuk menggunakan SPK online akan semakin tinggi dan pada akhirnya akan menggunakannya secara optimal dan menghasilkan kinerja terbaik. PBC dapat diartikan sebagai pandangan terhadap kesilitan atau kemudahan seseorang melakukan sesuatu. Niat polisi akan meningkat dalam menggunakan SPK online ketia ia merasa kesulitan yang dia alami Ketika menggunakannya dapat diatasi dengan mudah. Sedangkan jika bagi mereka kesulitan yang dialami tidak dapat ditangani, maka niat mereka menggunakan SPK online pun menurun.

Sesuai dengan theory of planned behavior oleh Ajzen \& Fishben (1970), terdapat faktor yang mempunyai karakteristik memperkuat dan memperlemah niat yaitu faktor pengendalian prilaku. Niat akan melemah apabila prilaku sulit dikendalikan atau tidak mungkin dilakukan. Hal ini sesuai dengan penelitian terdahulu yang dilakukan oleh Ruslim, dkk (2017) menentukan PBC berpengaruh signifikan terhadap niat. Hasil tersebut berbeda dengan hasil penelitian yang dilakukan oleh Yudhi, dkk (2015) yang membuktikan bahwa PBC memberikan pengaruh negatif terhadap niat. Hal ini dimungkinkan karena perbedaan karakter responden dan lokasi penelitian sehingga memiliki dampak yang berbeda.

Dilihat dari item kuesioner yakni PBC terhadap penggunaan SPK online menghasilkan bahwa PBC berpengaruh signifikan terhadap niat polisi menggunakan SPK online. Berarti dengan PBC yang semakin mendukung, mengakibatkan peningkatan niat polisi menggunakan SPK online secara signifikan. Variabel PBC menunjukkan besarnya kontribusi variabel PBC terhadap niat polisi menggunakan SPK online. Variabel PBC berkontribusi lebih kecil dibandingkan variabel sikap terhadap niat polisi menggunakan SPK online namun lebih besar dari variabel norma subjektif.

Sikap, norma subjektif dan PBC memberikan pengaruh yang positif dan signifikan terhadap niat polisi menggunakan SPK online pada Polsek Seririt Kabupaten Buleleng. Hal ini menunjukkan bahwa untuk meningkatkan niat polisi dalam menggunakan SPK online maka sikap, norma subjektif dan PBC harus dimiliki oleh setiap polisi dan merupakan penentu dari niat menggunakan SPK online. Terdapat tiga macam pertimbangan yang mendasari perilaku manusia berdasarkan TPB yakni keyakinan terhadap kecenderungan hasil positif atau negatif suatu perilaku (behavior belief), keyakinan akan harapan seseorang yang sifatnya normative (normative belief) serta keyakinan terhadap munculnya beberapa faktor yang menimbulkan perilaku (control belief) (Jogiyanto, 2007).

Dari hasil keseluruhan item kuesioner sikap, norma subjektif dan PBC terhadap niat polisi dalam menggunakan SPK online menunjukkan variabel sikap terhadap niat polisi menggunakan SPK online merupakan variabel yang dominan, dikarenakan sikap timbul dari keyakinan seseorang menegai sikap yang akan diambil. Hasil penelitian ini juga didukung oleh penelitian yang dilakukan Wikamorys dan Rochmach (2017), Seni dan Ratnadi (2017) dan Mirawati, dkk (2016) menunjukkan hasil bahwa sikap, norma subjektif dan PBC menunjukkan ada pengaruh yang signifikan terhadap niat.

Sistem penilaian kinerja merupakan sistem yang diterapkan agar dapat mengukur serta mengdentifikasi kinerja anggota POLRI agar sesuai dengan visi dan misi organisasi. SPK online yang dilakukan pada kantor Kepolisian Sektor Seririt diikuti oleh seluruh anggota yang bertugas di satuan tersebut. Dalam aplikasi SPK online terdapat beberapa data yang di input yakni kontrak kerja, nilai kontrak kerja, nilai tugas tambahan, form penilaian penghargaan, nilai faktor generik, faktor spesifik serta nilai akhir hasil penilaian kinerja anggota polisi. SPK online ini memudahkan untuk dapat dilakukan penarikan kesimpulan, evaluasi dan penilaian atas kinerja yang dilakukan oleh anggota kepolisian. 
SPK online ini juga diawasi dan didampingi oleh Atasan Pejabat Penilai (APP) dan Pejabat Penilai (PP). Tujuan penilaian kinerja untuk menjamin objektivitas dalam pembinaan karir, pendidikan pengembangan, kenaikan pangkat serta pemberian tunjangan kinerja. Dalam SPK online, waktu penilaian kinerja dalam satu tahun dilaksankan dua kali dimana semester satu dilakukan dari bulan Januari hingga bulan Juni kemudian semester dua dilakukan dari bulan Juli hingga bulan Desember. Sistem penilaian kinerja online ini berpengaruh terhadap proses kenaikan pangkat yang mana hal ini secara langsung berpengaruh juga terhadap bagaimana jenjang karir dan jabatan yang bisa ditempati oleh anggota kepolisian tersebut.

Adapun jenjang jabatan yang ada yakni sebagai, Ka SPKT, Panit Reskrim, Panit Intel, Panit Binmas, Panit Sabhara, Kanit Lantas, Kanit Provos serta Ka Sium. Sehingga untuk bisa menduduki jabatan atau posisi tersebut tergantung dari masa dinas untuk naik pangkat. Waktu yang diperlukan Polisi untuk naik pangkat relative cepat atau lambat tergantung dari prestasi serta pelanggaran yang dilakukan. Mulai pangkat Kompol hingga Jendral, kenaikan pangkat disesuaikan dengan pendidikan, prestasi, jabatan dan hasil assessment.

\section{Simpulan dan Saran}

Dari pembahasan yang telah dijelaskan diatas, dapat dibuat beberapa kesimpulan sebagai berikut. Sikap berpegaruh positif dan signifikan terhadap niat polisi menggunakan SPK online pada Polsek Seririt Kabupaten Buleleng. Hal ini menunjukkan semakin positif sikap polisi terhadap penggunaan SPK online maka semakin tinggi niat untuk menggunakannya. Sikap yang positif terbentuk karena anggota sudah merasakan kemudahan dan manfaat dari penggunaan SPK online. Penggunaan SPK online akan memudahkan anggota untuk melakukan penilaian kinerja dan menjaga agar data kinerja terarsipkan dengan baik dan sistematis, Norma subjektif memberikan pengaruh yang signifikan serta positif terhadap niat polisi menggunakan SPK online pada Polsek Seririt Kabupaten Buleleng. Niat polisi untuk menggunakan SPK online akan meningkat apabila mendapatkan dukungan dari orang lain sepeti keluarga, rekan kerja serta pimpinan, sehingga anggota satu sama lain saling memotivasi dan membantu dalam penggunaan SPK online, PBC berpengaruh positif dan signifikan terhadap niat polisi menggunakan SPK online pada Polsek Seririt Kabupaten Buleleng. Hal ini menunjukkan semakin tinggi PBC maka semakin tinggi pula niat polisi menggunakan SPK online. Polisi Polsek Seririt Kabupaten Buleleng yang menjadi responden memiliki kualifikasi dan kemampuan yang dibutuhkan untuk menggunakan SPK online secara penuh dan sesuai dengan prosedur, sehingga niatnya untuk menggunakan SPK online akan semakin tinggi dan pada akhirnya akan menggunakannya secara optimal dan menghasilkan kinerja terbaik, Sikap, norma subjektif dan PBC berpengaruh positif dan signifikan terhadap niat polisi menggunakan SPK online pada Polsek Seririt Kabupaten Buleleng. Hal ini menunjukkan bahwa untuk meningkatkan niat polisi dalam menggunakan SPK online maka sikap, norma subjektif dan PBC harus dimiliki oleh setiap polisi dan merupakan penentu dari niat menggunakan SPK online.

Adapun beberapa saran Bagi pihak yang memiliki jabatan dalam struktur organisasi dan koordinasi pada Polsek Seririt harus mensosialisasikan secara menyeluruh terhadap penggunaan SPK online dan memantau perkembangan sikap, norma subjektif dan PBC dari anggota sebagai pengguna sistem penilaian. Hal ini sudah dilaksanakan dengan baik melihat tingginya nilai sikap, saling memotivasi sebagai pengaruh norma subjekftif dan kemampuan kontrol diri sehingga mampu menggunakan SPK online dengan baik. Hal yang dilakukan selanjutnya adalah mempertahankan kondisi yang sudah kondusif ini sehingga tingkat pengaruh yang semula sebesar $89 \%$ dapat mencapai secara keseluruhan anggota yang bertugas di Polsek Seririt Kabupaten Buleleng.

Bagi peneliti yang tertarik untuk mengkaji aspek yang serupa yaitu pengaruh sikap, norma subjektif dan PBC terhadap niat menggunakan SPK online diharapkan untuk mengembangkan penelitian ini dengan menggunakan populasi dan sampel yang lebih luas agar hasil penelitian lebih teruji keandalannya. 


\section{Daftar Pustaka}

Ajzen, I., 1991. Theory of Planned Behavior. Organizational Behavior and Human Decision Processes, 179-211.

Ajzen, I., dan M. Fishbein. 1970. The prediction of behavior from attitudinal and normative variable. Journal of Experimental Social Psychology 6 (4) hal. 466-487.

Anggar, S \& Ratnadi. 2017. Theory of Planned Bahavior Untuk Memprediksi Niat Berinvestasi. Denpasar: E-Jurnal Ekonomi dan Bisnis Universitas Udayana.

Arikunto. 2013. Prosedur Penelitian Suatu Pendekatan Praktek. Jakarta: Rineka Cipta.

Hartono, Jogiyanto. 2007. Sistem Informasi Keprilakuan Edisi Revisi Yogyakarta: Andi.

Jogiyanto. 2008. Sistem informasi keprilakuan. Yogyakarta: Penerbit ANDI.

Mirawati, Wardana, dkk. 2016. Pengaruh Sikap, Norma Terhadap Niat Siswa SMK di Kota Denpasar Untuk Menjadi Wirausaha. Denpasar :E-Jurnal Ekonomi dan Bisnis Universitas Udayana.

Neely, A., Gregory, M. \& Platts, K. 1995. "Performance measurement system design: a literature review and research agenda". International Journal of Operations and Production Management, 15 (4) hlm. 80-116.

Sugiyono. 2010. Metode Penelitian Kuantitatif Kualitatif dan R\&D. Bandung: Alfabet.

Taylor, S., \& P. A. Todd. 1995. Understanding Information Technology Usage: A Test of Competing Models. Information System Research 6 (2) hlm. 144-176.

Yudhi, W. Arthana, dkk. 2015. Pengaruh Minat Individu Terhadap Penggunaan Mobile Banking (M-Banking): Kombinasi Thecnology Acceptance Model (TAM) dan Theory of Planned Behavior (TPB), Jurnal Informasi. 